\title{
REHABILITATION OUTCOMES IN FEMALES WITH SPINAL CORD INJURY: A FOLLOW-UP STUDY
}

By A. C. Pinkerton, M.B., Ch.B., F.R.C.P.(C) and M. L. Griffin, M.S.S.W.

G. F. Strong Rehabilitation Centre, Vancouver, B.C., Canada.

Summary. A follow-up study was carried out on patients with spinal cord injury discharged from the G. F. Strong Rehabilitation Centre, Vancouver, British Columbia, Canada over a five year period with a minimum time from discharge to follow up of I 8 months.

Those no longer residing in the province, under the age of sixteen years on discharge, or who had made a substantial recovery were eliminated from the study. All of the patients included required a wheelchair or other aids for ambulation and had loss of normal bowel and bladder control.

Twenty-four patients out of 37 who met the criteria were interviewed and details of medical, social, vocational and psychological outcomes are presented. In addition there were four deaths, the causes of which are discussed. Interesting comparisons between tetraplegic and paraplegic patients are given. Some differences between the findings in female and male patients are included.

Key words: Traumatic paraplegia and tetraplegia in females; Outcome of treatment; Adjustment; Comparisons with male patients.

\section{Method}

THE MEDICAL records of 285 patients, I 74 paraplegic and I I tetraplegic were reviewed, and of those 172 met the predetermined criteria. Interestingly 60 patients who required inpatient treatment in a rehabilitation centre after their acute care, recovered to an extent that they no longer had sufficient disability to qualify for the study. Of the 172 patients who met the criteria IO (four females) had died and of the remaining I62 patients 105 (8I males and 24 females) agreed to participate in a detailed follow up study (Table I).

The majority of those who did not wish to take part in the study had been seen since discharge either by one of the medical staff of the rehabilitation centre or by the Discharge Nurse-Co-ordinator. Information

TABLE I

Spinal cord injury females

\begin{tabular}{lrrr}
\hline & Para. & Tetra. & Total \\
\hline Discharged 5 year period & 4 I & 26 & 67 \\
Did not meet criteria & I 7 & 9 & 26 \\
Eligible & 24 & 1 7 & 4 I \\
Deceased & 4 & 0 & 4 \\
Participated & I 5 & 9 & 24 \\
\hline
\end{tabular}


available on these patients was not obtained in a standardised manner and so is not included in this report. A questionnaire was developed based on Trieschmann's three catergories of function relating to successful life. (Trieschmann, I980).

I. Prevention of medical complications - utilisation of activities of daily living and mobility skills (either by self-care or by influencing the environment in such a manner to ensure that appropriate care is received).

2. Maintenance of a stable living environment (required are all the social skills necessary to cope with society, family, friends, and the attendant of applicable).

3. Productivity (vocational, education, volunteer and hobby activities).

The questionnaire and interview procedure was designed to provide uniformity of information through structured questions and responses suitable for computer tabulation. Some latitude was however allowed to obtain additional information through open ended questions. Information was therefore gathered through completion of the questionnaire by personal interview in the participants' homes (M.L.G.) and from review of the medical records. All of the females in the study group were living at home and out of the total of 105 interviewed only six, all male, were in community care facilities.

Those categorised as complete may have had minimal sensory sparing below the level of their spinal cord lesion but they had no useful motor or sensory function below that level. All of those in the incomplete groups had significant motor or sensory sparing but they were still seriously disabled (Table II).

TABLE II

Level and degree of lesion

\begin{tabular}{|c|c|c|c|}
\hline & Para. & etra & Total \\
\hline Incomplete & 3 & 2 & 5 \\
\hline Complete & 12 & 7 & I9 \\
\hline
\end{tabular}

\section{Results}

\section{Age ranges}

The majority of both male and female patients were under 30 years of age at the time of injury. There was a slight increase in the incidence of females in the 40-49 group and in males in the 50-59 group; injuries in the latter being mainly due to falls. The oldest female in the study group was 52 years of age at the time of injury, whereas there were male participants in the 60 and over age groups (Table III).

\section{Causes}

The major cause of injury is a motor vehicle accident. Considerably more 
TABLE III

Age at injury

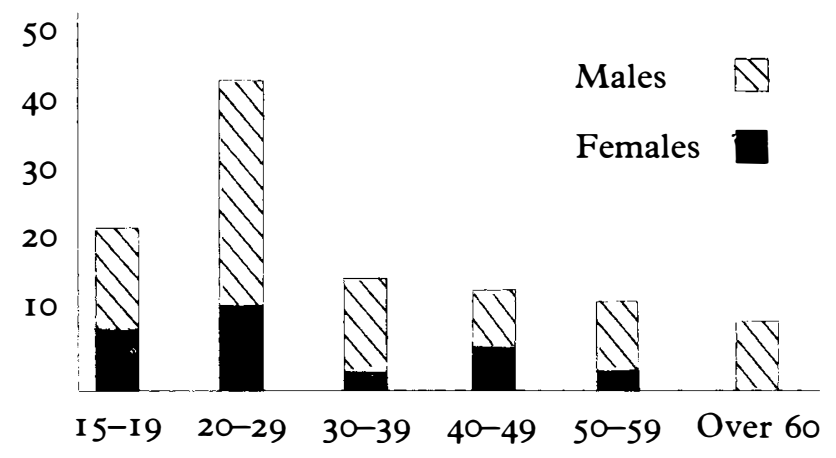

passengers than drivers were injured, and of the females involved the disproportion was even more marked with only two females being drivers. All of the sporting injuries occurred in males. Of those due to falls there were only five females out of a total of 34 . Injuries as a result of falls seem to occur more frequently in males and particularly in those over 50 years of age. Three females were injured in industrial accidents, one had a fall at school while working as a teacher's aide, another was injured working in the woods and the third was a pilot car driver returning to home base as a passenger in a truck (Table IV).

TABLE IV

Cause of injury

\begin{tabular}{|c|c|c|c|c|c|}
\hline & & & & & Totals \\
\hline & $\mathrm{F}$ & $\mathbf{M}$ & $\mathrm{F}$ & $\mathbf{M}$ & \\
\hline Vehicular & & & & & \\
\hline Auto accident-Driver & I & 12 & I & 5 & I9 \\
\hline -Passenger & 9 & I I & 6 & 6 & 32 \\
\hline Motor cycle & I & 3 & 0 & 4 & 8 \\
\hline Violence & 0 & I & 0 & I & 2 \\
\hline Falls/falling objects & & & & & \\
\hline -Non industrial & I & 9 & I & 3 & I 4 \\
\hline -Industrial & 2 & IO & I & 6 & 19 \\
\hline Sports & o & 3 & o & 6 & 9 \\
\hline Attempted suicide & I & 0 & 0 & 0 & I \\
\hline
\end{tabular}

\section{Education}

The females generally had a higher level of education than males at the time of injury. Nineteen out of $\mathbf{2 4}$ females had Grade I I education or better. There was however, a greater proportion of males with college or university qualifications. Nine of the females (seven paraplegic two 
tetraplegic) undertook further education following injury and all had attained Grade I I or I 2 level previously. They were in the younger range, the eldest being $2 \mathrm{I}$ years of age at the time of injury.

\section{Employment}

Ten were employed at injury. One returned to her former job as a bookkeeper while another changed from being a teacher's aide to a medical records technician. Three are students and are pursuing further education to improve their employability. Four are unemployed while the other is now a homemaker.

Of the eight who were students at injury, five were continuing their education and three were working in clerical-type jobs. One of these is a data processor and was the only tetraplegic patient in the post-injury employed group.

Three homemakers returned to homemaking duties after injury. The remaining three in the group were unemployed both at injury and at followup.

\section{Marital status}

Of the nine who were married at the time of injury two were widowed in the same accident in which they were injured. Five of the other seven remain married, one is separated and one divorced. Three married after becoming disabled and two of them remain married. Only one of the three cases of marital break-up was considered to be in any way related to disability.

\section{Pregnancies}

Four of the 24 females in the study group had pregnancies which proceeded to term. Three were paraplegic, two had TI I complete and one had a $\mathrm{L}_{\mathrm{I}}$ incomplete lesion. The other was a $\mathrm{C}_{5} / 6$ tetraplegic. In all cases this was their first completed pregnancy. The tetraplegic girl was the only one married prior to injury and she also had a miscarriage after her injury. She was the oldest of the group at the time of delivery, being 33 years of age. She had an indwelling catheter and had no particular difficulties during pregnancy other than some slight oedema of the feet and ankles. She went into labour spontaneously and after a few hours developed sweating and headache with each contraction but with no reported increase in blood pressure. Eventually after I 2 hours labour because of these distressing symptoms and a persistent transverse presentation, Caesarean section was performed and a full term infant weighing $8 \mathrm{lbs}$ I oz was delivered. The post partum convalescence was uncomplicated and she breast fed her baby for two months. The baby developed pyloric stenosis but this was corrected surgically at two months and thereafter development was uneventful.

The three paraplegic girls all had spinal fusions with Harrington Rods. Labour was spontaneous and delivery vaginal without complications. Two continued with intermittent self catheterisation throughout pregnancy and labour, while the third had elected to have an indwelling catheter as a matter of convenience prior to becoming pregnant. She is a TI I complete paraplegic and had problems of increased oedema and spasticity in the third trimester. 
None of the four had any additional genitourinary difficulties during pregnancy. The shortest time from injury to delivery was three years. Although of no particular importance it is interesting that they all produced male children.

\section{Income}

There was no great change in income level pre- and post-injury, the numbers with lower incomes being balanced by those with higher incomes.

Proportionately the female group had a greater number in the higher income group than the males, which may have been due to a greater number of females receiving insurance settlements at a relatively early stage after injury as they were mostly passengers rather than drivers.

\section{Accommodation}

The living situations at the time of interview are shown in Tables V and VI.

TABLE V

Accommodation at interview

\begin{tabular}{lccr}
\hline & Para. & Tetra. & Total \\
\hline Parents home & 2 & I & 3 \\
Own home & 6 & 6 & I 2 \\
Relatives home & 0 & I & I \\
Rental apartment & 5 & 0 & 5 \\
Subsidised handicapped & & & \\
$\quad$ housing & 0 & I & I \\
Mobile home & I & 0 & I \\
Board and room & I & 0 & I \\
\hline
\end{tabular}

Table VI

Where living at the interview

\begin{tabular}{lrrr}
\hline & Para. & Tetra. & Total \\
\hline Family & I I & 7 & I 8 \\
Friend & 0 & I & I \\
Alone & 4 & I & 5 \\
\hline
\end{tabular}

Six out of the 24 lived in small communities with the remainder being in medium to large urban areas. All were living in accessible architecturally acceptable accommodation.

\section{Independence}

All of the paraplegics were completely independent in activities of daily living. Three of the tetraplegics, two incomplete and the other a $\mathrm{C}_{7}$ complete lesion were independent in dressing, grooming, transfers and bowel and 
bladder management. Another tetraplegic was capable of chair to bed transfer while yet another required only minor assistance.

\section{Bladder management}

Seven of the tetraplegics had indwelling catheters while the other two, both with incomplete lesions, were able to void on a reflex basis and remain continent. Only one of the paraplegics had an indwelling catheter, I I used intermittent self catheterisation while the other three voided by manual expression. Very few instances of incontinence were reported. The percentage of females with indwelling catheters compares with that reported by Thomas and Clarke (1979). They however did not use intermittent catheterisation in female patients whereas we have found this method of bladder drainage particularly useful in the female.

\section{Bowel function}

Seven out of the nine tetraplegics had satisfactory bowel function on an every second or third day basis using digital stimulation and varying use of simple laxatives. Six of them used suppositories in addition to digital stimulation. Two of the group had not developed a regular routine but had very few involuntary bowel movements. Only three tetraplegics did not require assistance to defaecate. All of the paraplegics had satisfactory bowel function with five using suppositories and digital stimulation and another three digital stimulation only. The others were able to have a bowel movement on a timed basis.

\section{Driver training}

Sixteen received driver training during their rehabilitation 12 paraplegics and four tetraplegics. At the time of interview all 12 paraplegics were driving independently but only two of the tetraplegics. The only difference between males and females in terms of driver training and driving, was that proportionately more male than female tetraplegics were driving.

\section{Complications and hospitalisations}

Fifteen out of the 24 had been readmitted to acute hospitals between the time of discharge from the rehabilitation centre and the follow up interview. The total number of hospital admissions for the group was 39. Genitourinary causes accounting for nearly half of the total admissions. All but four of the readmissions to hospital were for periods of less than 2 I days. Ten patients, four paraplegic and six tetraplegic had further inpatient treatment at the rehabilitation centre following their initial discharge, for the purpose of either reassessment or upgrading. Although the number of readmissions may seem high, it should be appreciated that many were for routine genitourinary follow up and not necessarily because of the development of complications.

Females maintained their health better than males. The male patients had a greater number of hospitalisations and for longer periods than the females. This was due mainly to a number of males who developed complications in the early post-injury period with continuing problems post discharge requiring frequent and sometimes lengthy hospitalisation. 
Interference with activities

Responses to questions about the extent to which disability interfered with activities are in Table VII.

TABLE VII

Problems interferring with activities (responses of participants)

\begin{tabular}{lccc}
\hline & $\begin{array}{c}\text { Very } \\
\text { limiting }\end{array}$ & $\begin{array}{c}\text { Slightly } \\
\text { limiting }\end{array}$ & $\begin{array}{c}\text { No } \\
\text { interference }\end{array}$ \\
\hline Bladder & 4 & I0 & 10 \\
Skin & 0 & 6 & 18 \\
Respiratory & I & 2 & 21 \\
Spasms & 2 & 7 & 15 \\
Pain & 5 & 6 & 13 \\
Depression & 0 & 2 & 22 \\
\hline
\end{tabular}

Although few instances of incontinence were reported, the need to carry out regular self intermittent catheterisation was considered by many to interfere with their freedom of action. Only one of those complaining of pain being very limiting was under 40 years of age. All with pain had continuing complaints from the time of injury. Four were tetraplegic and were very limited in their physical activities for other reasons. None were taking analgesic drugs to excess.

\section{Stress on families}

Surprisingly few perceived their tetraplegic or paraplegic state as causing undue stress on family or friends. Three tetraplegics thought that there was significant strain on the family because of the burden of physical care which they required and two paraplegics because of the way in which their disability interfered with family activities.

\section{Compliance}

Nine out of the 24 patients (five paraplegic four tetraplegic) were considered to be lacking in motivation, unco-operative or non-compliant during their rehabilitation. However, only three of the nine (one paraplegic and two tetraplegic) had not in our judgement made a satisfactory social and personal adjustment at the time of interview.

\section{Activities}

The figures in Table VIII indicate that as a group the females lead varied and active lives. Only daily or weekly participation in the activities listed is recorded but others were involved on a less frequent basis. For example two not included in the table do volunteer work regularly so that in total one third of the group provide service to others as volunteers. 
TABLE VIII

Activities

\begin{tabular}{lrrrr}
\hline & \multicolumn{2}{c}{ Daily } & \multicolumn{2}{c}{ Weekly } \\
& Para. & Tetra. & Para. & Tetra. \\
\hline Household activity & I 2 & 2 & 3 & 4 \\
Child care & 5 & 3 & I & 0 \\
Radio/TV/stereo & I I & 8 & 3 & I \\
Reading & IO & 2 & 4 & 2 \\
Hobbies & 3 & 3 & 9 & I \\
Visitors/visiting & 3 & 3 & IO & 4 \\
Shopping & I & 0 & I 3 & 5 \\
Group activities & 3 & 0 & 6 & 2 \\
Volunteer work & 0 & 0 & 4 & 2 \\
\hline
\end{tabular}

TABLE IX

Life satisfaction

\begin{tabular}{lccc}
\hline & \multicolumn{3}{c}{ Somewhat } \\
& Satis. & dissatis. & Dissatis. \\
\hline Living arrangements & 23 & 0 & I \\
Family relationships & 23 & I & 0 \\
Finances & I 8 & 4 & 2 \\
Sex $^{\star}$ & 9 & 6 & 4 \\
Social life & I9 & 3 & 2 \\
General health & I 9 & 3 & 2 \\
Transportation & I 7 & 2 & 5 \\
Work (those employed) & 4 & 0 & I \\
\hline
\end{tabular}

${ }^{\star}$ Five not included see text

\section{Emotional status}

All reported some degree of frequency of frustration with one third being frustrated frequently (four paraplegic, four tetraplegic). Causes of frustration were generally related to limitations resulting from their disability. Reaction to frustration varied. Some took positive action such as discussing their feelings with others but the majority reacted negatively by becoming angry, anxious, depressed and withdrawn.

Twenty-two of the group experienced episodes in which they felt depressed. Over one half also admitted to having had thoughts of suicide. All but one who reported thoughts of suicide continued to have these thoughts after completion of the rehabilitation programme. The majority were able to cope objectively and successfully with depression and thoughts of suicide and did so by obtaining support from family members as well as from professionals. True depressive disorder was a relatively infrequent finding and this is in keeping with the report of Howell et al. (I98I).

\section{Life satisfaction}

Perception of life satisfaction indicated that most had positive feelings about 
TABLE X

Deaths

\begin{tabular}{lll}
\hline & F & M \\
\hline Suicide & 3 & 3 \\
Respiratory & 0 & 2 \\
G.U. & I & I \\
& - & $-6(4.6 \%)$ \\
& - & - \\
\hline
\end{tabular}

their overall situation. The subjects of transportation and sex evoked the greatest number of negative responses (Table IX).

Five of the group who were not sexually active did not answer the questions pertaining to sex but all expressed acceptance of their sex role and had no wish at that time for change.

\section{Deaths}

There were Io deaths in the total group of I72. Four females out of $4 \mathrm{I}$ and six males out of I3 I (Table X). All of the females who died and five out of six males who died were paraplegic. Although it might appear that there was a greater incidence of both death and suicide in the female group, the figures are not in fact statistically significant. There was a high proportion of suicides only one of whom, a female was injured in a suicidal attempt. All were under 30 years of age and were paraplegic except for one male patient. Five of the six suicides were from drug ingestion including the one injured in a suicidal attempt, while the other, a female, was by hanging. The remaining female death was from septicaemia and kidney failure in a patient who seemed disinterested in looking after herself. In some respects this death might also be considered to be a type of suicide. She died 4 years after injury when 30 years of age. The other genitourinary death was from acute pyelonephitis in a 45-year-old man just under one year from the time of injury. One of the respiratory deaths was from bronchopheumonia in a 58 -year-old man with a TI2 paraplegia $2 \frac{1}{2}$ years following injury. The other was in a 34-year-old seriously disabled but incomplete C4-5 tetraplegic whose cause of death was given as bronchopneumonia. He had discharged himself from an extended care institution a few days previously and had given indications that he intended to terminate his life. This death therefore, may also have been suicide.

The three female suicides were all in their twenties. Two of them were single. The other was listed as widowed, her husband having committed suicide a year prior to her injury and one year after the breakup of the marriage.

Financial factors did not seem to be related to the suicidal deaths, nor did family relationships or cause of disability.

\section{Conclusion}

The numbers in this study were small and the fact that only those discharged over a five year period were included makes detailed comparisons with other reports inappropriate. 
Some negative aspects were uncovered, such as the incidence of feelings of depression and frustration. This illustrates the need for more emphasis to be placed during the rehabilitation period on programmes designed to improve coping skills and social interaction. The number of deaths from suicide is also rather disturbing and indicates that further research in this area is required. Nevertheless it would appear that females with spinal cord injury are by and large functioning very well in the community. Many positive features of life satisfaction such as living arrangements, family relationships, social activities and pursuit of further education were noted.

The results of this study indicate that there are aspects of the rehabilitation programme which should be reviewed and that efforts to improve our knowledge and methods of treatment must continue. Yet notwithstanding the myriad problems which they face from day to day, females are managing to deal with the paraplegic or tetraplegic state in a remarkably successfuil way.

\section{RÉSUMÉ}

Une étude post-réadaptation d'une dureé de cing ans a été effectueé aupres de personnes leseés de la moëlle épinière qui ont eu leur congé de G. F. Strong Rehabilitation Centre, Vancouver, Colombie Britannique, Canada, le temps minimum depuis le congé étant de dix huit mois.

Celles que ne demeuraient plus daus la province, sous lâge de seize ans au moment du congé ou celles qui auraient eu une récupération substentielle ont été élimineés de l'étude. Tous les patients inclus dans l'étude faisaient usage d'un fauteuil roulant ou d'aides techniques pour leur déplacements et avaient perdus le contrôle de leurs fonctions urinaire et intestinale.

Vingt-quatre des trent-sept qui rencontraient les critères requis par l'étude, furent intervieweés et des détails sur les resultats médicaux, sociaux, vocationnels et psychologigues sont prěsentés. De plus quatre étaient décédes au moment de l'enquête; les causes sont également discutées. Des comparaisons intéressants entre tétraplégiques et paraplégiques sont mentionnées. Des differences entre hommes et femmes sone incluses également.

\section{ZUSAMMENFASSUNG}

Ein NachfolgeStudium wurde durch geführt mit Rückgrat verletzten Patienten welche entlassen wurden von G. F. Strong Rehabilitation Centre, Vancouver, British Columbia, Canada über eine Periode von fünf Jahren, mit einer Minimum Zeitspanne von Entlassung bis zur Nachfolge von achtzehn Monaten.

Diejenigen, die nicht mehr in der Provinz vohnten, unter dem Alter von sechzehn Jahren a.Zt.der Entlassung waren oder jene welche eine starke Genesung machten, wurden ausgeschieden von dem Studium. Alle Patienten eingescholossen brauchten einen Rollstuhl oder eine andere Hilfe zum Gehen und hatten keine normale Kontrolle über ihre Blase oder Gedärme.

Von sieben und dreissig Patienten, vier und zwanzig erreichten das Kriterium, und wurden befragt. Die Einzelheiten von medizinischen, gesellschaftlichen beruflichen und psychologlgischen Ergebnis sen wurden prässentitert. Im Zusatz waren vier Todesfälle, von welchen die Ursache erörtert wurde. Eine interessante Vergleichung zwischen tetraplegien und paraplegien Patienten wurde gegeben, einige Unterschiede im Befunde zwischen weiblichen und männlichen Patienten waren beigelegt.

\section{REFERENCES}

Howell, T., Fullerton, D. T., Harvey, R. F. \& Klein, M. (I98I). Depression in spinal cord injured patients. Paraplegia, 5, 284.

Thomas, D. G. \& Clarke, S. J. (I 979). The urological status of 86 females following spinal cord injury. British fournal of Urology, 51, 515-5I7.

Trieschmann, R. B. (1980). Spinal Cord Injuries: Psychological Social E Vocational Adjustment, pp. I I2-I I3, Pergamon Press Inc., New York. 